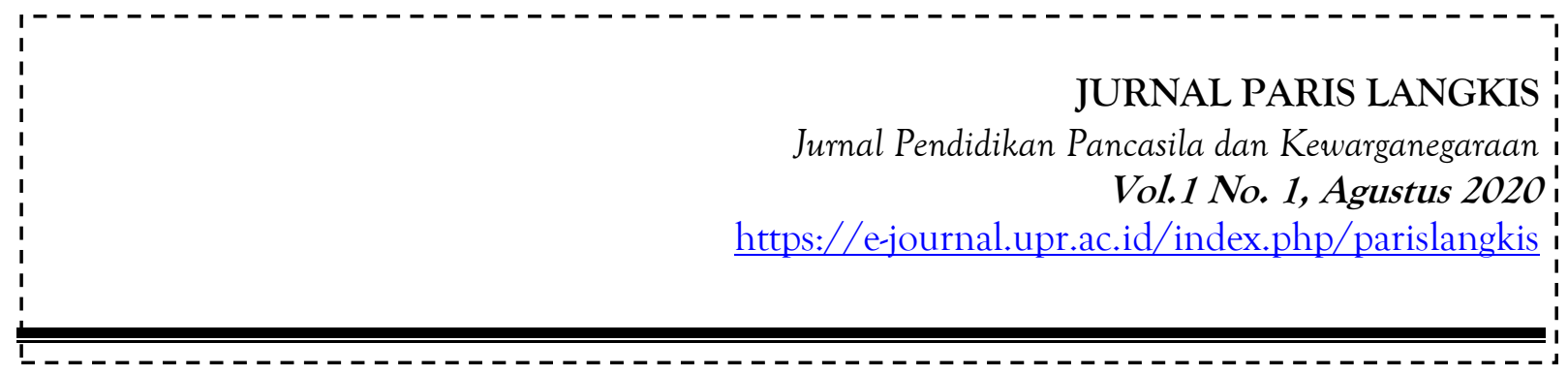

\title{
KONTRIBUSI LINGKUNGAN BELAJAR DAN SARANA PRASARANA TERHADAP HASIL BELAJAR SISWA MATA PELAJARAN TIK (Studi Kasus Kelas XI IPS SMA PGRI 1 Padang)
}

\author{
Menrisal $^{1^{*}}$, Popi Radyuli ${ }^{2}$, Darma Sanjaya ${ }^{3}$, Zakia Zuzanti ${ }^{4}$ \\ ${ }_{1,2,3}$ Pendidikan Teknologi Informasi, Fakultas Keguruan Ilmu Pendidikan, Universitas Putra Indonesia \\ "YPTK" Padang \\ ${ }^{4}$ Prodi Bimbingan dan Konseling, Universitas Negeri Padang \\ e-mail:menrisal@gmail.com ${ }^{1}$,darma.sanjaya2395@gmial.com²,zkzuzanti@gmail.com²
}

\begin{abstract}
Abstrak:
Penelitian ini bertujuan untuk mengetahui besarnya kontribusi lingkungan belajar dan sarana prasarana terhadap hasil belajar siswa pada mata pelajaran TIK kelas XI IPS SMA PGRI 1 Padang. Hasil analisis data menunjukkan hubugan lingkungan belajar dengan hasil belajar sebesar $r_{\text {hitung }}>r_{\text {tabel }}(0,278<0,195)$, terdapat hubungan yang positif dan signifikan dan dilanjutkan dengan uji $t$ sebesar $t_{\text {hitung }}>t_{\text {tabel }}(2,469>1,658)$ sebesar $11,25 \%$, hipotesis pertama diterima, sarana prasarana dengan hasil belajar sebesar $r_{\text {hitung }}>r_{\text {tabel }}(0,126>0,195)$, terdapat hubungan yang positif dan signifikan dan dilanjutkan dengan uji $t$ sebesar $t_{\text {hitung }}>t_{\text {tabel }}$ $(1,257>1,658)$ sebesar 9,94\% hipotesis kedua di terima, lingkungan belajar dan sarana prasarana dengan hasil belajar secara bersama-sama sebesar $r_{\text {hitung }}>r_{\text {tabel }}(0,242>0,195)$, terdapat hubungan yang positif dan signifikan dan dilanjutkan dengan uji $f$ sebesar $F_{\text {hitung }}>F_{\text {Tabel }}$ $(2,469>1,658)$ sebesar $9,80 \%$ hipotesis ketiga di terima pada mata pelajaran TIK siswa kelas XI IPS SMA PGRI 1 Padang.
\end{abstract}

Kata Kunci : Lingkungan Belajar; Sarana Prasarana Dan Hasil Belajar

\section{Abstract:}

This Research aims to determine the contrbution of learning environment and infrastructure to student learning outcomes to the results, of class XI IPS student on the subjects ICT senior high school PGRI 1 Padang. The results of the analysis of the data showed: relationship environment learning the learning results of $r_{\text {hitung }}>r_{\text {tabel }}(0,278<0,195)$, there is apositive and significant corerelation and continued $t$ tes amount $t_{\text {hitung }}>t_{\text {tabel }}(2,469>1,658)$ the first hypothesis isreceived, relationsip the infractructur outcomes learning of $r_{\text {hitung }}>r_{\text {tabel }}(0,126>0,195)$, there is apositive and significant corerelation and continued $t$ tes amount $t_{\text {hitung }}>t_{\text {tabel }}(1,257>1,658)$, the second hypothesis isaccepted, the school environment and attitudes towards learning outcomes learning together amounted to $r_{\text {hitung }}>r_{\text {tabel }}(0,242>0,195)$, there is apositive and

\section{Paris Langkis}


significant corerelation and continued $f$ tes amount $F_{\text {hitung }}>F_{\text {Tabel }}(2,469>1,658)$ the third hipthesis is accepted in subjects XI IPS Senior High School PGRI 1 Padang.

Keywords: Learning Evirotment and Infrastructure; Study Results

\section{A. PENDAHULUAN}

Pendidikan mempunyai fungsi yang harus diperhatikan seperti dapat dilihat pada UU No.22 tahun 2003 pasal 3 yang menyatakan bahwa: "Pendidikan nasional berfungsi mengembangkan kemampuan dan membentuk watak serta peradaban bangsa yang bermartabat dalam rangka mencerdaskan kehidupan bangsa, bertujuan untuk berkembangnya potensi peserta didik agar menjadi manusia yang beriman dan bertaqwa pada Tuhan Yang Maha Esa, beraklaq mulia, sehat berilmu, cakap, kreatif, mandiri dan menjadi warga yang demokratis dan bertanggung jawab”. Menurut Ngalim Purwanto (1988: 148) lingkungan pendidikan atau lingkungan belajar dibedakan menjadi 3 golongan. antara lain: lingkungan keluarga, lingkungan sekolah dan lingkuangan masyarakat. Lingkungan belajar tersebut mendukung dan berperan besar dalam keberhasilan perestasi belajar anak didik.

Sekolah merupakan lembaga pendidikan formal yang memungkinkan seseorang meningkatkan pengetahuan dan mengembangkan bakat yang dimilikinya. Dikatakan sebagai lembaga pendidikan formal karena diadakan di sekolah atau tempat tertentu dan mempunyai jenjang mulai dari pendidikan dasar, pendidikan menengah, dan pendidikan tinggi. Hal itu sesuai dengan Undang-Undang Republik Indonesia No. 20 tahun 2003 tentang system pendidikan nasional Bab VI pasal 14. Pendidikan dasar merupakan pendidikan yang bertujuan untuk mengembangkan sikap dan kemampuan serta memberikan pengetahuan dan keterampilan dasar yang diperlukan untuk hidup dalam lingkungan masyarakat. Dan sekaligus mempersiapkan peserta didik untuk melanjutkan pendidikan ketingkat menengah. Pendidikan dasar ini diselengarakan selama 12 tahun, yang dilaksanakan 6 tahun di Sekolah Dasar (SD) dan Madrasah Ibtidaiah (MI) atau bentuk lain yang sederajat, serta 3 tahun di Sekolah Lanjutan Tingkat Pertama (SLTP) dan Madrasah Tsanawiyah (MTS) atau bentuk lain yang sederajat dan sekolah menengah pertama (SMA/SMK).Penulis diminta untuk membaca petunjuk dengan hati-hati. Penulis bertanggung jawab untuk semua materi yang disajikan di makalah.

\section{B. KAJIAN TEORI}

1) Pengertian Hasil Belajar

Hasil belajar adalah perubahan perilaku pada diri seseorang akibat tindak belajar yang mengcakup sifat kognitif (intelektual), bidang sikap (afektif), dan bidang perilaku piskomotorik, dan merupakan hasil dari suatu proses belajar mengajar yang memberikan informasi tentang sejauh mana dia menguasai materi pelajaran, bukan suatu penguasaan hasil latihan, melainkan perubahan kelakuan, sesuatu yang di capai atau di peroleh siswa berkat danya usaha atau fikiran hal tersebut di nyatankan dalam bentuk penguasaan, pengetahuan dan kecakapan dasar yang terdapat dalam berbagai aspek kehidupan sehingga nampak pada diri individu pengunaan penilaian terhadap sikap, sehingga nampak pada diri individu perubahan tingkah laku. 


\section{2) Pengertian Lingkungan Belajar}

Pengertian lingkungan belajar adalah tempat berlangsungnya kegiatan belajar yang mendapatkan pengaruh dari luar terhadap keberlangsungan kegiatan tersebut macam-macam Lingkungan Belajar Menurut Ki Hajar Dewantara, lingkungan pendidikan mencakup :1) lingkungan keluarga, 2) lingkungan sekolah, dan 3) lingkungan masyarakat Lingkungan keluarga menurut Slameto ( 2003:60-64 ), siswa yang belajar akan menerima pengaruh dari keluarga berupa cara orang tua mendidik, relasi antara anggota keluarga, suasana rumah, keadaan ekonomi keluarga, pengertian orang tua, dan latar belakang kebudayaan.

\section{1) Pengertian Sarana Prasarana}

Dalam khazanah peristilahan pendidikan sering disebut-sebut istilah sarana dan prasarana pendidikan. kerap kali istilah itu digabung begitu saja menjadi sarana-prasarana pendidikan, dalam bahasa Inggris sarana dan prasarana itu disebut dengan facility (facilities). Jadi, sarana dan prasarana pendidikan akan disebut educational facilities. Sebutan itu jika diadopsi ke dalam bahasa Indonesia akan menjadi fasilitas pendidikan. fasilitas pendidikan artinya segala sesuatu (alat dan barang) yang memfasilitasi (memberikan kemudahan) dalam menyelenggarakan kegiatan pendidikan. Sarana belajar bisa melalui media sosial yang saat ini sedang marak digunakan, seperti watsApp, Instagram, Facebook, serta aplikasi LMS (Learning Managemen System) lainnya yang dapat digunakan menjadi sarana pembelajaran(Saefulloh, 2018a). Sarana tersebut tidak terlepas dari penggunaan internet, maka perlu adanya peran pendidik yang terorganisir dalam pelaksanaannya(Saefulloh, 2018b). Media tersebut juga dapat diterapkan pada pembelajaran Improve terhadap hasil belajar siswa yang membutuhkan fasilitas berupa sarana pembelajaran secara daring (Risma Yunita \& Menrisal Menrisal, 2017).

\section{METODE PENELITIAN}

Metode yang digunakan dalam penelitian ini adalah kuantitatif dengan jenis penelitian yaitu korelasional. Korelasional adalah suatu penelitian untuk menentukan tingkat hubungan antara variabel penelitian yang berbeda serta besarnya kontribusi variable bebas terhadap variabel terikat. Penelitian korelasi atau korelasional adalah suatu penelitian untuk mengetahui hubungan dan tingkat hubungan antara dua variable atau lebih tanpa ada upaya untuk mempengaruhi variable tersebut sehingga tidak terdapat manipulasi variable(faenkel dan wallen,2008:328). Penelitian korelasi ini dipilih karena peneliti ingin menyelidiki hubungan antara beberapa variable, secara bersama-sama (simultan). Disamping itu, penelitian korelasi juga dapat memberikan informasi tentang derajat (kekuatan) hubungan antara variable-variabel yang diteliti.

Variabel yang dimaksud dalam penelitian ini terdiri dari dua variabel yaitu Lingkungann belajar dan Sarana prasarana sekolah menjadi variabel bebas (X), sedangkan variabel terikat adalah Hasil belajar $(\mathrm{Y})$. Penelitian kuantitatif digunakan pada penelitian ini untuk menggambarkan hubungan lingkungan belajar dan sarana prasarana dengan hasil belajar siswa pada mata pelajaran TIK kelas XI IPS di SMA PGRI 1 Padang. 


\section{1) Lingkungan Belajar (X1)}

Data variabel lingkungan belajar dikumpulkan melalui angket yang terdiri dari 35 butir pernyataan yang telah diuji validitas dan reliabilitasnya. Selanjutnya angket diberikan kepada 100 orang responden untuk diisi. Berdasarkan perhitungan statistik pada tabel 16 dapat dilihat bahwa variabel lingkungan belajar dengan jumlah data $(\mathrm{N})$ sebanyak 100, mean 146,23, median 147, mode 144, standar deviasi 13,911, varians 193,523, Skor Minimum 172, skor maksimum 117 range 55, dan skor total keseluruhan sebesar 14623.

Gambaran distribusi frekuensi skor lingkungan belajar dapat dilihat pada tabel 17 berikut ini

Tabel 17 : Distribusi Frekuensi Skor Linkungan Belajar $\left(\mathrm{X}_{1}\right)$

\begin{tabular}{ccccc}
\hline \multirow{2}{*}{ NO } & \multicolumn{4}{c}{ Variabel $\left(\mathbf{X}_{1)}\right.$} \\
\cline { 2 - 5 } & Interval Skor & $\begin{array}{c}\text { Frekuensi } \\
\text { Mutlak }\end{array}$ & $\begin{array}{c}\text { Frekuensi Relatif } \\
(\%)\end{array}$ & $\begin{array}{c}\text { Frekuensi } \\
\text { Kumulatif (\%) }\end{array}$ \\
\hline 1 & $117-123$ & 4 & 4 & 4 \\
2 & $124-130$ & 8 & 8 & 12 \\
3 & $131-137$ & 10 & 10 & 22 \\
4 & $138-144$ & 22 & 22 & 44 \\
5 & $145-151$ & 24 & 24 & 68 \\
6 & $152-158$ & 14 & 14 & 82 \\
7 & $159-165$ & 15 & 15 & 97 \\
8 & $166-172$ & 3 & 3 & 100 \\
\hline Jumlah & 100 & 100 & & \\
\hline
\end{tabular}

Berdasarkan tabel 17 diatas, terlihat distribusi frekuensi skor lingkungan belajar dimana dalam menentukan hitungan jarak atau rentang, jumlah kelas interval serta banyaknya kelas. Berikut ini histogram dari distribusi frekuensi lingkungan belajar siswa.

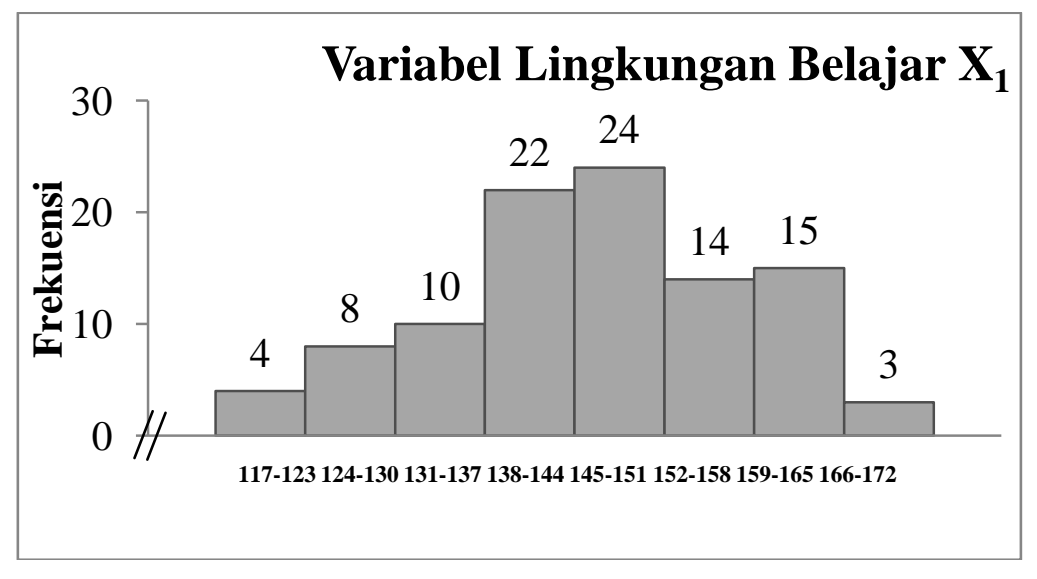

Gambar 2 : Histogram Frekuensi Lingkungan Bejar

Berdasarkan gambar diatas diperoleh gambaran bahwa interval jawaban tertinggi pada kelas interval 145-151 dengan frekuensi 24 orang dan tingkat pencapaian skor lingkungan belajar $85.01 \%$ termasuk dalam kategori cukup.

2) Sarana Prasarana (X2) 
Data variabel sarana prasarana dikumpulkan melalui angket yang terdiri dari 34 butir pernyataan yang telah diuji validitas dan reliabilitasnya. Selanjutnya angket diberikan kepada 100 orang responden untuk diisi. Berdasarkan perhitungan statistik pada tabel dapat dilihat bahwa variabel srana prasarana dengan jumlah data $(\mathrm{N})$ sebanyak 100, mean 141,53, median 381, mode 144, standar deviasi 13,911, varians 193,523, Skor Minimum 107, skor maksimum 167 range 60 dan skor total keseluruhan sebesar 14153.

Tabel 18 : Distribusi Frekuensi Variabel Sarana Prasarana (X2)

\begin{tabular}{ccccc}
\hline NO & $\begin{array}{c}\text { Interval } \\
\text { Skor }\end{array}$ & $\begin{array}{c}\text { Frekuensi } \\
\text { Mutlak }\end{array}$ & $\begin{array}{c}\text { Frekuensi Relatif } \\
(\%)\end{array}$ & Frekuensi Kumulatif (\%) \\
\hline 1 & $107-114$ & 3 & 3 & 3 \\
2 & $115-122$ & 3 & 3 & 6 \\
3 & $123-129$ & 12 & 12 & 18 \\
4 & $130-137$ & 20 & 20 & 38 \\
5 & $138-145$ & 24 & 24 & 62 \\
6 & $146-153$ & 20 & 20 & 84 \\
7 & $154-161$ & 13 & 13 & 95 \\
8 & $162-169$ & 5 & 5 & 100 \\
\hline Jumlah & 100 & 100 & & \\
\hline
\end{tabular}

Berdasarkan tabel 18 terlihat distribusi frekuensi skor sarana prasarana dimana dalam menentukan hitungan jarak atau rentang, jumlah kelas interval serta banyaknya kelas. Berikut ini histogram dari distribusi frekuensi lingkungan belajar siswa

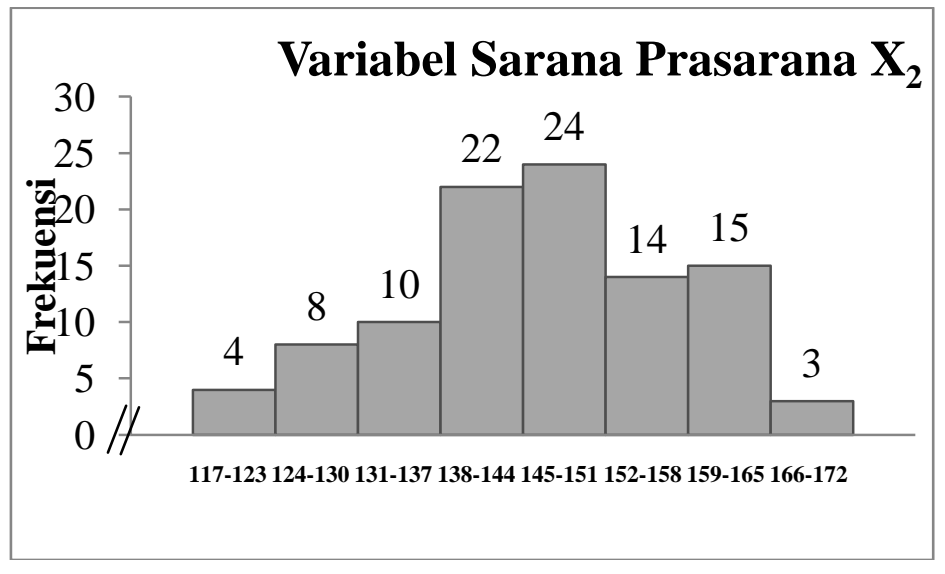

Gambar 3 : Histogram Sarana prasarana 
Berdasarkan gambar diatas diperoleh gambaran bahwa interval jawaban tertinggi pada kelas interval 138-145 dengan frekuensi 24 orang tingkat pencapaian skor sarana prasarana sebesar $84,74 \%$ termasuk dalam kategori cukup.

\section{3) Hasil Belajar (Y)}

Data variabel Hasil belajar dikumpulkan melalui angket yang terdiri dari 35 butir pernyataan yang telah diuji validitas dan reliabilitasnya. Selanjutnya angket diberikan kepada 100 orang responden untuk diisi. Berdasarkan perhitungan statistik pada tabel dapat dilihat bahwa variabel kecerdasan emosional dengan jumlah data $(\mathrm{N})$ sebanyak 100, mean 83,36, median 84, mode 83, standar deviasi 7,518, varians 56,528, Skor Minimum 68, skor maksimum 100, range 32 dan skor total keseluruhan sebesar 8336 .

Tabel 19 : Distribusi Frekuensi Variabel Hasil Belajar (Y)

\begin{tabular}{ccccc}
\hline \multirow{2}{*}{ NO } & \multicolumn{4}{c}{ Variabel $\left(\mathbf{X}_{2)}\right.$} \\
\cline { 2 - 5 } & $\begin{array}{c}\text { Interval } \\
\text { Skor }\end{array}$ & $\begin{array}{c}\text { Frekuensi } \\
\text { Mutlak }\end{array}$ & $\begin{array}{c}\text { Frekuensi Relatif } \\
(\%)\end{array}$ & $\begin{array}{c}\text { Frekuensi Kumulatif } \\
(\%)\end{array}$ \\
\hline 1 & $68-76$ & 13 & 13 & 13 \\
2 & $77-85$ & 48 & 48 & 61 \\
3 & $86-94$ & 34 & 34 & 95 \\
4 & $95-100$ & 5 & 5 & 100 \\
\hline Jumlah & 100 & 100 & &
\end{tabular}

Berdasarkan tabel 19 terlihat distribusi frekuensi skor hasil belajar dimana dalam menentukan hitungan jarak atau rentang, jumlah kelas interval serta banyaknya kelas. Berikut histogram dari distribusi frekuensi hasil belajar.

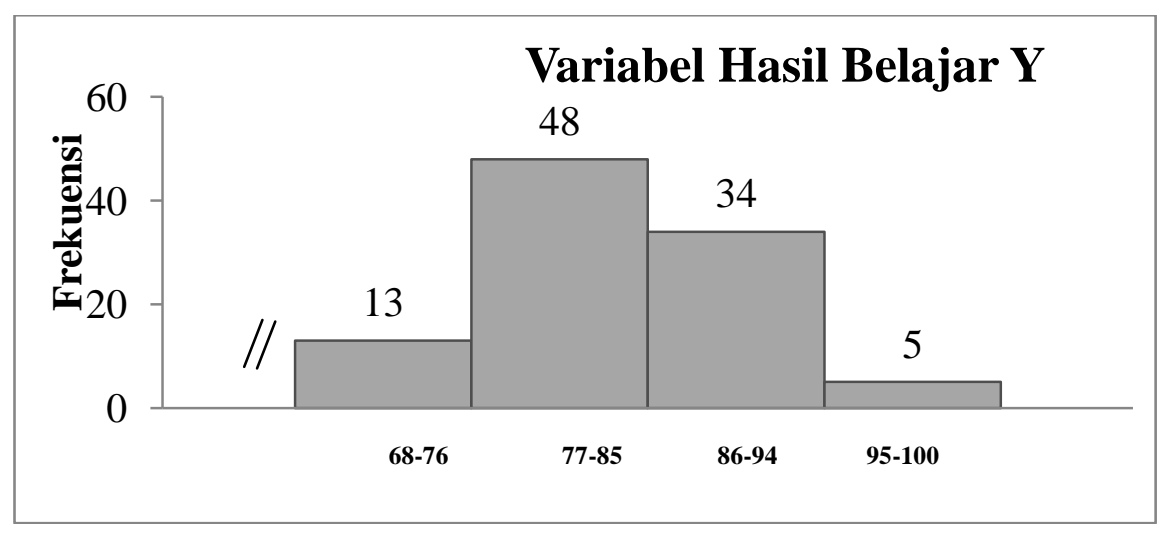

Gambar 4 : Histogram Hasil Belajar

4) Persyaratan uji Analisis

a) Uji Normalitas

Uji normalitas digunakan untuk mengetahui apakah populasi data berdistribusi normal atau tidak. Uji normalitas dilakukan dengan menggunakan rumus Lilifors yang dihitung secara manual.

Tabel 20 : Hasil Uji Normalitas 


\begin{tabular}{ccccccc}
\hline No & Variabel & $\mathbf{N}$ & $\mathrm{L}_{\mathrm{o}}$ & $\mathrm{L}_{\mathrm{t}}$ & Perbandingan & Ket. \\
\hline 1 & $\mathrm{X}_{1}$ & 100 & $-0,0026$ & 0,0623 & $\mathrm{~L}_{\mathrm{o}}<\mathrm{L}_{\mathrm{t}}$ & Normal \\
2 & $\mathrm{X}_{2}$ & 100 & 0,0064 & 0,0623 & $\mathrm{~L}_{\mathrm{o}}<\mathrm{L}_{\mathrm{t}}$ & Normal \\
3 & $\mathrm{Y}$ & 100 & 0,0035 & 0,0623 & $\mathrm{~L}_{\mathrm{o}}<\mathrm{L}_{\mathrm{t}}$ & Normal \\
\hline
\end{tabular}

Dari tabel 20 diatas dapat dilihat bahwa skor signifikasi untuk kecerdasan emosional dan kecerdasan spiritual terhadap hasil belajar siswa diperoleh $\mathrm{L}_{0}$ untuk variabel $\mathrm{X}_{1}$ sebesar -0,0026, untuk variabel $\mathrm{X}_{2}$ sebesar 0,0064 dan untuk variabel $\mathrm{Y}$ sebesar 0,0035.

Sedangkan $L_{t}$ sebesar 0,0623 yang diperoleh dari nilai kritis $L$ untuk uji Lilliefors. Karena hasilnya $\mathrm{L}_{0}<\mathrm{L}_{\mathrm{t}}$ maka sampel dikatakan berdistribusi normal. Maka persyaratan uji linearitas dapat dilakukan.

\section{b) Uji Linieritas}

Uji linieritas bertujuan untuk mengetahui apakah dua variabel mempunyai hubungan yang linier atau tidak secara signifikan. Uji linieritas biasanya digunakan sebagai prasyarat dalam analisis korelasi atau regresi linier.

\begin{tabular}{lllll}
\hline Variabel & Sig. & Fhitung & Ftable & Kriteria \\
\hline X1-X2-Y & 0,05 & 261,602 & 1,658 & Linear \\
\hline
\end{tabular}

\section{c) Uji Hipotesis}

Setelah melakukan uji normalitas dan uji linearitas yang sudah memenuhi syarat, maka dapat dinyatakan bahwa data kecerdasan emosional dan kecerdasan spiritual terhadap hasil belajar mempunyai distribusi normal dan linear. Selanjutnya, pengujian hipotesis dilakukan untuk menentukan besarnya dilakukan untuk menentukan besarnya kontribusi dengan menggunakan uji kefisien korelasi yang berfungsi untuk mengetahui besarnya hubungan antar variabel baik secara sendiri maupun bersama-sama dan untuk menguji apakah hipotesis yang diajukan diterima atau ditolak. Pengujian dilakukan dengan uji t.

\section{d) Korelasi Sederhana}

Uji korelasi sederhana dilakukan untuk menyatakan berapa besar kontribusi antara satu variabel bebas dengan satu variabel terikat. Uji hipotesis bertujuan untuk menguji apakah hipotesis yang dilakukan diterima atau ditolak.

Kontribusi Antara $X_{1}$ terhadap $Y$

Tabel 22 : Hasil Perhitungan Korelasi Product Moment $\mathrm{X}_{1}$

\begin{tabular}{llll}
\hline Hipotesis & $\mathbf{r}_{\text {hitung }}$ & $\mathbf{r}_{\text {tabel }}$ & Kriteria \\
\hline $\mathrm{X}_{1} \mathrm{Y}$ & 0,242 & 0,195 & Hipotesis Diterima \\
\hline
\end{tabular}


Berdasarkan tabel didapatkan hasil bahwa $r_{\text {hitung }}>r_{\text {tabel }}$ sehingga dapat disimpulkan bahwa hipotesis pertama di terima. Jadi tidak adanya korelasi yang positif dan signifikan antara lingkungan belajar terhadap hasil belajar $\left(\mathrm{X}_{1}-\mathrm{Y}\right)$.

\section{Kontribusi Antara $X_{2}$ terhadap Y}

Tabel 23 : Hasil Perhitungan Korelasi Product Moment $\mathrm{X}_{2}$

\begin{tabular}{llll}
\hline Hipotesis & $\mathbf{r}_{\text {hitung }}$ & $\mathbf{r}_{\text {tabel }}$ & Kriteria \\
\hline $\mathrm{X}_{2} \mathrm{Y}$ & 0,126 & 0,195 & Hipotesis Diterima
\end{tabular}

Berdasarkan tabel didapatkan hasil bahwa $r_{\text {hitung }}>r_{\text {tabel }}$ sehingga dapat disimpulkan bahwa hipotesis pertama diterima. Jadi adanya korelasi yang positif dan signifikan antara sarana prasana terhadap hasil belajar $\left(\mathrm{X}_{2}-\mathrm{Y}\right)$.

Kontribusi Antara $X_{1}$ dengan $X_{2}$

Tabel 24 : Hasil Perhitungan Korelasi Product Moment $\mathrm{X}_{1}$

\begin{tabular}{lccl}
\hline Hipotesis & $\mathbf{r}_{\text {hitung }}$ & $\mathbf{r}_{\text {tabel }}$ & Kriteria \\
\hline X1-X2 & 0,482 & 0,195 & Hipotesis Diterima
\end{tabular}

Berdasarkan tabel didapatkan hasil bahwa $r_{\text {hitung }}>r_{\text {tabel }}$ sehingga dapat disimpulkan bahwa hipotesis pertama diterima. Jadi adanya korelasi yang positif dan signifikan antara lingkungan belajar dengan sarana prasarana (X1-X2).

\section{e) Uji Signifikansi}

Uji signifikansi dilakukan dengan menggunakan rumus uji $t$, dari hasil pengujian $t$ didapatkan nilai $t_{\text {hitung }}$ kemudian dibandingkan dengan $t_{\text {tabel }}$.

Tabel 25 : Hasil Perhitungan Uji t

\begin{tabular}{llll}
\hline Hipotesis & $\mathbf{t}_{\text {hitung }}$ & $\begin{array}{l}\mathbf{t}_{\text {tabel }} \\
(\mathbf{5 \%})\end{array}$ & Ket \\
\hline $\mathrm{X}_{1}-\mathrm{Y}$ & 2,469 & 1,658 & Hipotesis Pertama Diterima \\
$\mathrm{X}_{2}-\mathrm{Y}$ & 1,267 & 1,658 & Hipotesis Kedua Diterima \\
\hline
\end{tabular}

Berdasarkan tabel dapat dikatakan $t_{\text {hitung }}>t_{\text {tabel }}$ maka hipotesis pertama dan kedua diterima. Jadi dapat ditarik kesimpulan adanya kontribusi yang positif dan signifikan antara lingkungan belajar terhadap hasil belajar $\left(\mathrm{X}_{1}-\mathrm{Y}\right)$ dan sarana prasarana terhadap hasil belajar $\left(\mathrm{X}_{2}-\mathrm{Y}\right)$ siswa kelas XI IPS di SMA PGRI 1.

\section{f) Korelasi Ganda}


Uji korelasi ganda dilakukan untuk menyatakan berapa besar kontribusi antara dua variabel bebas atau lebih dan satu variabel terikat. Hasil uji korelasi ganda dapat dilihat berdasarkan lampiran 19 halaman 152 yang hasilnya $\mathrm{r}_{\text {hitung }}>\mathrm{r}_{\text {tabel }}(0,278>0,195)$.

Tabel 26 : Hasil Perhitungan Uji F

\begin{tabular}{cccc}
\hline Hipotesis & $\mathrm{F}_{\text {hitung }}$ & $\mathrm{F}_{\text {tabel }}(5 \%)$ & Ket \\
\hline $\mathrm{X}_{1} \mathrm{X}_{2}-\mathrm{Y}$ & 7,72 & 1,658 & Hipotesis Ketiga Diterima \\
\hline
\end{tabular}

Berdasarkan tabel didapatkan hasil bahwa $\mathrm{F}_{\text {hitung }}>\mathrm{F}_{\text {tabel, }}$, sehingga dapat disimpulkan bahwa hipotesis ketiga diterima. Jadi adanya kontrbusi yang positif dan signifikan antara lingkungan belajar $\left(\mathrm{X}_{1}\right)$ dan sarana prasarana $\left(\mathrm{X}_{2}\right)$ terhadap hasil belajar $(\mathrm{Y})$.

\section{HASIL DAN PEMBAHASAN}

Berdasarkan Hasil analisis penelitian tentang perhitungan kontribusi lingkungan belajar terhadap hasil belajar hasilnya adalah $r_{\text {hitung }}>r_{\text {tabel }}(0,278<0,195)$, dan uji signifikan menggunakan uji $\mathrm{t}$, sehingga memperoleh hasil antara lingkungan belajar terhadap hasil belajar $t_{\text {hitung }}>t_{\text {tabel }}(2,469>1,658)$, sehingga dikatakan bahwa ada pengaruh yang positif dan signifikan antara variabel $\mathrm{X}_{1}$ (lingkungan belajar) terhadap $\mathrm{Y}$ (hasil belajar) sebesar 11,25\%. Hasil penelitian ini diperkuat oleh. Slameto (2003: 60) mengemukakan bahwa lingkungan belajar siswa yang berpengaruh terhadap hasil belajar siswa terdiri dari lingkungan keluarga, lingkungan sekolah dan lingkungan masyarakat.

Selanjutnya pendapat ahli telah dibuktikan oleh penelitian terdahulu Lisa Angraini (2008), skrips dengan judul : "Kontribusi lingkungan belajar terhadap hasil belajar siswa kelas X SMA Negeri 13 Padang tahun ajaran 2009/2010”. Dari hasil penelitian diperoleh lingkungan belajar berpengaruh positif dan signifikan terhadap hasil belajar mata pelajaran TIK maka hipotesis peneliti diterima. Besarnya kontribusi lingkungan belajar terhadap hasil belajar mata pelajaran TIK yaitu sebesar 43,6\%. Diantara lingkungan belajar yang memberikan pengaruh paling besar terhadap hasil belajar mata pelajaran TIK adalah lingkungan sekolah yaitu sebesar 35,2\% sedangkan lingkungan keluarga berpengaruh lebih kecil sebesar 28,2\%.

Kemudian, Hasil analisis penelitian tentang perhitungan kontribusi sarana prasarana terhadap hasil belajar adalah $r_{\text {hitung }}>r_{\text {tabel }}(0,126>0,195)$, kemudian dilakukan uji $t$ antara lingkungan belajar terhadap hasil belajar $t_{\text {hitung }}>t_{\text {tabel }}(1,267>1,658)$, sehingga memperoleh hasil yang positif dan signifikan antara variabel $\mathrm{X}_{2}$ (lingkungan belajar) terhadap $\mathrm{Y}$ (hasil belajar siswa) sebesar 9,94\%.

Hasil penelitian ini diperkuat oleh Djamarah (2009:92) sarana atau fasilitas merupakan penunjang tercapainya tujuan pendidikan. Dengan tersedianya alat sarana dan prasarana yang memadai diharapkan siswa dapat memperoleh hasil belajar yang baik, sehingga nantinya dapat memperoleh prestasi belajar yang baik. Faktor yang berkaitan dan berhubungan dengan pelajaran komputer. Sarana dan prasarana komputer mempengaruhi secara langsung proses belajar mengajar. Sarana dan prasarana laboratorium komputer yang baik,diperkirakan akan menghasilkan prestasi belajar siswa yang baik pula.

Selanjutnya pendapat ahli telah dibuktikan oleh penelitian terdahulu yaitu Carolus Adi Pruwono (2014) yang berjudul "Kontribusi Lingkungan Belajar dan Sarana Prasarana Terhadap Hasil Belajar Siswa Kelas XI IPS SMA Negeri 3 Padang Tahun Ajaran 2013/2014”. Dalam penelitian tersebut dapat disimpulkan bahwa terdapat kontribusi positif dan signifikan 
terhadap hasil belajar mata pelajaran TIK sebesar 40,5\%. Lingkungan belajar memberikan kontribusi pada mata pelajaran TIK sebesar 35,8\%. Dan sedangkan lingkungan memberikan kontribusi sebesar 25,4\%.

Berdasarkan hasil perhitungan kontribusi lingkungan belajar dan sarana prasarana terhadap hasil belajar hasilnya adalah $r_{\text {hitung }}>r_{\text {tabel }}(0,242>0,195)$, dan dilakukan uji $F$ untuk keduanya antara lingkungan belajar dan sarana prasarana terhadap hasil belajar memperoleh $\mathrm{F}_{\text {hitung }}>\mathrm{F}_{\text {Tabel }}(2,469>1,658)$. Sehingga dapat dikatakan bahwa kontribusi dalam penelitian dikatakan positif dan signifikan antara lingkungan belajar dan sarana prasarana terhadap hasil belajar mata pelajaran TIK siswa kelas XI IPS SMA PGRI 1 Padang sebesar 9,80\%. Dinyatakan bahwa hipotesis ketiga diterima.

Hasil penelitian ini di perkuat oleh Slamento (2013:71) jika dilingkungan belajar anak didukung oleh sarana dan prasarana yang cukup, maka akan mempengaruhi kemauan anak untuk belajar. Pengaruh itu dapat mendorong semangat anak untuk belajar lebih giat lagi.

Selanjutnya pendapat ahli telah dibuktikan oleh penelitian terdahulu Deri Krispan Darma (2010), skripsi dengan judul : "Kontribusi Minat Belajar Dan Lingkungan Belajar Siswa Terhadap Hasil Belajar Teknologi Informasi Dan Komunikasi Kelas X SMA Pembangunan Padang" hasilnya Minat belajar memberikan kontribusi sebesar 17,4\% terhadap hasil belajar Teknologi Informasi Dan Komunikasi siswa kelas X SMA Pembanguna Padang. Lingkungan belajar memberikan kontribusi sebesar 19,5\% terhadap hasil belajar Teknologi Informasi Dan Komunikasi siswa kelas X SMA Pembangunan Padang. Minat belajar dan lingkungan belajar secara bersama-sama memberikan kontribusi sebesar 30,3\% terhadap hasil belajar Teknologi Informasi Dan Komunikasi siswa kelas X SMA Pembangunan Padang. Dimana semakin baik minat belajar dan lingkungan belajar maka semakin baik pula hasil belajar yang dicapai siswa.

Oleh karena itu karna lingkungan belajar yang dekat dengan pasar dan dan wisata banyak siswa yang terpengaruh dan banyaknya siswa yang keluar perkarangan sekolah pada jam belajar jadi sekolah harus meningkatkan lagi disiplin, dan lingkungan keluarga orang tua sangat berperan penting dalm pendidikan anak seperti perhatian, biaya pendidikan sangat menentukan hasil belajar anak. sarana prasarana yang masih kurang, agar bisa di lengkapi dan di perhatikan baik kepala sekolah, maupun guru untuk mencapai suatu tujuan pembelajaran, agar terjadi pembelajaran yang seimbang untuk meningkatkan hasil belajar yang diharapkan

\section{E. KESIMPULAN}

1. Dari penelitian yang telah dilakukan tentang hubungan lingkungan belajar dan sarana prasarana terhadap hasil belajar mempunyai kesimpulan sebagai berikut :

2. Hasil analisis penelitian tentang perhitungan kontribusi lingkungan belajar terhadap hasil belajar hasilnya adalah $r_{\text {hitung }}>r_{\text {tabel }}(0,278<0,195)$, dan uji signifikan menggunakan uji $t$, sehingga memperoleh hasil antara lingkungan belajar terhadap hasil belajar $t_{\text {hitung }}>t_{\text {tabel }}$ $(2,469>1,658)$, sehingga dikatakan bahwa ada pengaruh yang positif dan signifikan antara variabel $\mathrm{X}_{1}$ (lingkungan belajar) terhadap Y (hasil belajar) sebesar 11,25\%.

3. Hasil analisis penelitian tentang perhitungan kontribusi sarana prasarana terhadap hasil belajar adalah $r_{\text {hitung }}>r_{\text {tabel }}(0,126>0,195)$, kemudian dilakukan uji $t$ antara lingkungan belajar terhadap hasil belajar $\mathrm{t}_{\text {hitung }}>\mathrm{t}_{\text {tabel }}(1,257>1,658)$, sehingga memperoleh hasil yang positif dan signifikan antara variabel $\mathrm{X}_{2}$ (lingkungan belajar) terhadap $\mathrm{Y}$ (hasil belajar siswa) sebesar 9,94\%. 
4. Hasil perhitungan kontribusi lingkungan belajar dan sarana prasarana terhadap hasil belajar hasilnya adalah $r_{\text {hitung }}>r_{\text {tabel }}(0,242>0,195)$, dan dilakukan uji $\mathrm{F}$ untuk keduanya antara lingkungan belajar dan sarana prasarana terhadap hasil belajar memperoleh $\mathrm{F}_{\text {hitung }}>$ $\mathrm{F}_{\text {Tabel }}(2,469>1,658)$. Sehingga dapat dikatakan bahwa hubungan dalam penelitian dikatakan positif dan signifikan antara lingkungan belajar dan sarana prasarana dengan hasil belajar mata pelajaran TIK siswa kelas XI IPS SMA PGRI 1 Padang sebesar 9,80\%. Dinyatakan bahwa hipotesis ketiga diterima. 


\section{REFERENSI}

Anas, Sudijono. 2007. Penganta Statistik Pendidikan .Jakarta :Rajawali Pers. . 2011. Pengantar Evaluasi Pendidikan. Jakarta :Rajawali Pers.

Agung. 2005. Metodologi Penelitian Pendidikan. Singaraja: STKIP Singaraja.

Bafadal,Ibrahim.2003. Manajemen Peningkatan Mutu Sekolah Dasar, Sentralisasi menuju Desentralisasi.Jakarta:Bumi Aksara

Djamarah, Syaiful Bahri, 2009. Psikologi Pendidikan, Jakarta, PT. Rineka Cipta.

Fitri, Hugraheni.2010.Hubungan Lingkungan Belajar Terhadap Hasil Belajar Mahasiswa.Skripsi. Jogjakarta : Fakutas Ekonomi UKM.

Gagne, dalam Dimyanti dan Mudjiono, 2002, Belajar dan Pembelajaran, Jakarta:Rineka Cipta.

Harum, Rasyid. 2008. Penilaian Hasil Belajar. Bandung: cv Wacana Citra.

Nasution . 2004, Didaktik Asas-asas Mengajar, Jakarta: Bumi Aksara.

Oemar, Hamalik. 2001 . Prses Belajar Mengajar. Jakarta:PT Bumi Aksara

Purwanto. 2009. Evaluasi Hasil Belajar.Yogayakarta:PustakaPelajar.

Riduwan. 2013. Belajar Mudah Penelitian.Bandung: Alfabeta

Rita, Handayani. 2010 .Hubungan Motivasi Belajar Terhadap Prestasi Bealar Geografis SISWA KELAS $X$ dan XI IPS SMA N 1 Minggir Sleman.Skripsi. Yogyakarta:Universitas Negeri Jogyakarta.

Rohman, Natawijaya. 1979. Psikologi Pendidikan. Jakarta: Prindo Jaya.

Risma Yunita, \& Menrisal Menrisal. (2017). Pengaruh Penerapan Metode Pembelajaran Improve Terhadap Hasil Belajar Siswa Mata Pelajaran Teknologi Informasi dan Komunikasi (TIK) (Studi Kasus Kelas XI SMAN 12 Padang). Jurnal Kajian Bimbingan Dan Konseling.

Saefulloh, A. (2018a). Penggunaan Aplikasi Whatsapp Sebagai Metode Pembelajaran di SMP IT Nurul Ilmi Jambi. Jurnal An-Nahdhah, 12(2), 126-145. Retrieved from https://journal.staimaarif-jambi.ac.id/index.php/annahdhah/article/view/156

Saefulloh, A. (2018b). PERAN PENDIDIK DALAM PENERAPAN INTERNET SEHAT MENURUT ISLAM. Al-Tadzkiyyah: Jurnal Pendidikan Islam. https://doi.org/10.24042/atjpi.v9i1.2709

Sanjaya. 2010. Strategi Pembelajaran (Berorientasi Standar Proses Pendidikan). Jakarta : Prenada Media Group

Sudjana. 2005. Pengantar Evaluasi Pendidikan. Bandung: Raja Grafindo Persada.

Sugiyono.2014. Metode Penelitian Kuantitatif kualitatif dan REDD. Bandung:Alfabeta.

SuharsimiArikunto. 2006.Manajemen Pengajaran Secara Manusiawi. Jakarta: RinekaCipta. 2013. Dasar-Dasar Evaluasi Pendidikan. Jakarta:Bumi Aksara.

Tulus Tu,u. 2004. Peran Disiplin Pada Perilaku dan Prestasi Belajar. Jakarta:Grasindo 